\title{
PARATHYROID CATARACT
}

BY

Paul Weinstein, M.D.

BUDAPEST

Parathyroid cataract is one of the less frequent forms of cataract. Parathyroid cataracts may be grouped in postoperative, spontaneous, and experimental types. Records of numerous studies directed to the clinical occurrence of parathyroid cataract are found in the literature. (Wettendorfer, Branbergen, Peters, Hesse, Phleps Erdheim, Possek, Pineles, Hayano, Hiroishi, Lawrence, Sainton, Dorothy Rose Adams, Marcove, O'Brein, etc.). Its histology has been also subject of intensive studies. (Goldmann, Cosmettatos, Vogt, P(elláthy, Heine, Knüsel, Kast, etc.) Aetiulogical factors, (s?e Hesse, Phleps, Fischer-Triebenstein, Mamoli, Nelson, Tron, etc.,) suggest that some of the senile cataracts may also be due to parathyroid disturbances. In addition to latent parathyroid tetany being successfully proved in a great many patients of adianced age there seems to be a marked neurological connection between zonular cataract and parathyroid tetany. Goldmann supports the view that cataracts secondary to parathyroid tetany are due to a special reaction of the lens-fibres towards toxic substances produced in the body. As the parathyroids have a well established rôle in calcium metabolism, some authors even suggest the possibility of a relation of parathyroid cataract to blood-calcium.

Reiss, Jess, Goldschmidt, Tasmann-Karr and others found a definite decrease in the cysteine content of lenses suffering from senile cataracts, or rather a transformation of cysteine into cystine. This change affects the transparency of the lens, produces grey spots by upsetting the lens metabolism, and the respiration.

Whereas the normal lens gives a positive cysteine reaction, the spot treated with one drop of 4 per cent. sodium nitro-prusside + one drop of concentrated ammonia exhibits a crimson red colour : (Nitro-prusside Reaction.) Lenses suffering from senile cataract fail to g:ve this reaction, at least on their grey parts. I reported my studies directed to the cysteine test of the lens-capsule, and of some lenses suffering from less frequent forms of cataract in a previous paper. References to the literature will be found in the same. My observations proved that the capsule of the lens keeps a positive cysteine test for the longest period. The cysteine test was equally positive in three cases of posterior cortical cataract, in one of parathyroid, and in one case of zonular cataract. I continued those studies since, and I am able to report in this paper the cysteine reaction (N.P.R.) and their bearings in two more 
cases of parathyroid and five cases of zonular cataract as well as in that of a cataract produced in vitro.

Cataract operations were performed on two patients suffering from parathyroid tetany in our hospital last year.

O. J., aged 32 years, female patient. In 1917, an attack of tetanic spasms occurred four days after strumectomy. A decreased vision was observed four months after the operation. Tetanic spasms occurred repcatedly since, the patient's hair had fallen out and her vision diminished gradually. In 1926, lobular extraction on the right eye. In 1931, the same operation performed on the left eye. Positive Chvostek, and Trousseau signs. This case exhibited tetanic symptoms combined with a cataract both due to an operation.

P. I., aged 45 years, female patient. In December, 1931, she came to our out-patient department with the complaint of decrease of vision progressing gradually for two weeks on both eyes. Further complaint : dyspnoea, and spasms of her extremities for several years. Medical examination revealed parathyroid tetany. Grey lenses were found on both eyes, being of a subcapsular character as proved by means of a slit-lamp. (Vogt.) Blood calcium 8.42 per cent. then and 7.48 per cent. three months later. In December, 1931, lobular extraction was performed on the left eye, which was followed by the same operation on the right eye in March, 1932. This patient exhibited a spontaneous parathyroid tetany.

We found the lens considerably reduced in the sagittal direction in the first case, which Kast believes to be characteristic of parathyroid cataract. The lens extracted without its capsule gave a definite N.P.R.

Technical difficulties prevented me from carrying out the reaction on the first extracted lens of the second case. The lens extracted four months later gave a definitely positive N.P.R.

Besides these two cases positive N.P.R. was found in five cases of zonular cataract.

On the basis of these results we may corroborate the assumption of Hesse-Phleps : the aetiological connection between zonular cataract and parathyroid tetany. Jess found that experimental naphthalene cataract equally exhibits positivecysteine test. Because of all these facts we feel inclined to believe that parathyroid and zonular cataract, as well as posterior cortical cataract, may be placed in a group of toxic cataracts. As is contrary to senile cataracts all the above mentioned cataracts give a positive N.P.R. in spite of their dimming, just as traumatic cataracts. There must be a well-marked difference between the mechanism of the origin of toxic and traumatic cataracts on one hand, and senile cataracts on the other.

The reactions supplying the oxidizing energy within the lens 
are reduced in senile cataracts. The origin of toxic and traumatic cataracts is similar with respect to this reaction. In traumatic cataracts the capsule of the lens bursts first, the aqueous humour flows through the gap thus produced into the lens; and puffs up its fibres. This is followed by a change of $\mathrm{pH}$ of lens substance, which produces the coagulation of proteins (Scalinci, Buglia, etc.).

According to Biedl the toxic agents, tyramine, histamine, and guanidine, produced in parathyroid tetany accumulate in the blood. I observed that the opacification of the lens in parathyroid tetany advances in layers. Toxic materials are produced at the time of tetanic spasms. These materials penetrate through the capsule and effect the opacification of the subcapsular part of the lens. In the period of rest a proliferation starts from the capsule, and that gives rise to a normal transparent layer, which develops as long as a new attack does not produce a new grey layer.

The possibility of a latent tetany exhibited by patients suffering from zonular and posterior cortical cataracts explains the increased permeability of the capsule permitting the absorption of toxic substances which produce a change in the $\mathrm{pH}$, and in the calcium content of the aqueous humour. Thus more colloidal chemical changes may be responsible for the opacification of the lens without the cysteine metabolism being necessarily altered in its biological mechanism.

The cysteine reaction of a pig's lens dimmed in vitro by hypertonic $\mathrm{NaCl}$ solution was found to be positive. I also obtained a positive reaction on a lens the proteins of which were coagulated by heat boiling of the lens.

The rôle of blood calcium in cataracts is very dubious. While certain authors (Tron, Adams, etc.) reported an increased bloodcalcium, others, (Pelláthy, etc.,) obtained normal values; total calcium was even found to be reduced in parathyroid tetany. The same was found in our cases. Baráth called attention to the importance of the different calcium fractions in addition to total calcium. In order to elucidate this problem comparative calcium determinations are being made in our hospital in normal patients, and in those suffering from cataract.

\section{BIBLIOGRAPHY}

Adams, Dorothy Rose.-The rôle of calcium in senile cataract, Bioch. Jl., Vol. XXIII, p. 902, 1929.

Barath.-Die experim. u. klin. Grundlagen der Therapie mit Calciumsalzen. 1931. Edmunds.- Double cataract following experimental total Thyroidectomy in a dog. The Ophthalmoscope, Vol. XIV, p. 140, 1916.

J. Fischer, $O$. Triebenstein.-Untersuchungen ueber Tetanie und Altersstar. Klin. Monatsbl.f. Augenhei,k., Vol. LII, 1914.

Goldmann.-Experimentelle Tetaniekatarakt. Arch. f. Ophthal., Vol. CXXII, p. 146, 1929. Heine.-Ueber Tetanie-und Myotoniekatarakt. Zeitschr. f. Augenheilk., Vol.
LV, p. 1, 1925. 
Hesse-Phleps.-Schichtsstar und Tetanie. Zèitschr. f. Augenheilk., Vol. XXIX, p. 238, 1913.

Kast.-Katarakt nach Strumektomie. Zeitschr.f. Augenheilk., Vol. LIX, p. 357, 1926.

Knüse1.-Das Spaltlampenbild der postoperativen Tetaniekatarakt. Arch. f. Ophthal., Vol. CXIV, p. 636, 1924.

Lawrence.-Cataract and postoperative tetany. Zentralbl. f. Ophthal., Vol. XX, p. 356, 1929.

Marcove.-Parathyreoid cataract. Amer. Jl. of Ophthal., Vol. XIV, p. 887, 1931.

Nelson.-Experim. Beitr. zur Frage d. Kalksstoffwechsels bei der Tetanie. Klin. Monatsbl. f. Augenheilk., Vol. LXX, p. 641, 1923.

O'Brien.-The cataract of postoperative tetany. Arch. of Ophthal., Vol. VI, p. 1, 1932.

Pellathy.-Calciumgehaltuntersuchungen im Blutserum bei Altersstar und die Ursachen der Cataracta senilis. Klin. Monatsbl. f. Augenheilk., Vol. LXXIX, p. 179, 1927.

Pineles.-Tetaniestar-Zuckerstar-Altersstar. Wien. klin. Wochenschr., p. 691, 1906.

Stoelzner.-Ueber Tetaniekatarakt. Zeitschr.f. Kinder., p. 425, 1913.

Tassmann-Karr.-Glutathione in crystalline Lens Arch. of Ophthal., p. 431, 1929.

Tron.-Die Bedeutung der Epithelkörperchen in der Pathologie des Altersstars. Arch. f. Augenheilk., Vol. XCVII, p. 356, 1926.

Vogt.-Lehrbuch und Atlas der Spaltlampenmikroskopie des lebenden Auges. II. Teil. Linse und Zonula. 1931.

Weinstein.-Zur Frage des physiko-chemischen Entstehungsmechanismus der Katarakte. Klin. Monatsbl. f, Augenheilk., Vol. LXXXVII, p. 393, 1931.

\section{ANNOTATION}

\section{The Association of Dispensing Opticians, Ltd.}

Two letters from the Association of Dispensing Opticians, should be of interest to ophthalmic surgeons. The first points out that if ophthalmic surgeons send patients to have a prescription for glasses made up to any firm of sight-testing opticians, there is a distinct possibility that such patients may be induced on future occasions to return to the sight-testing optician instead of re-visiting the ophthalmic surgeon. In this connexion it is pointed out that in an article in the Optician, of December 23, 1932, it is stated that a sight-testing optician went so far as to refuse to dispense the prescription of an ophthalmic surgeon. The Optician condemns this attitude giving as one reason the possibility of the sight-testing optician being able to wean the patient from consulting an ophthalmic surgeon in the future, by pointing out that the services of the latter in a case of refraction for glasses are unessential. Comment is almost unnecessary. In our opinion the sight-testing optician who adopts such practices is more likely to injure himself, in the estimation of the intelligent members of the public, than the ophthalmic surgeon. 